\title{
Food retailers' buying behaviour: An analysis in 16 European countries
}

\author{
Hans Skytte \& Niels J. Blunch \\ The MAPP Centre, The Aarhus School of Business, Department of Marketing, Haslegaardsvej 10, DK - 8210 Aarhus V, Denmark. \\ Phone+45894864 87,Fax: +45861501 77,E-mailsky@asb.dk
}

\begin{abstract}
This paper presents results from a study on food retailer buying behaviour, i.e., how the retailers judge product and vendor attributes when choosing a new supplier of a product category that is already well known to them. A conjoint analysis was conducted in 16 Western European countries. The study encompassed the retailers' buying behaviour for fish and cheese products. The results demonstrate that the traditional four P's are losing ground to some previously neglected attributes, which now demand consideration by retail suppliers of products and services and by researchers.
\end{abstract}

Key words: retailers' buying behaviour, food products, conjoint analysis

\section{The objective of the study}

The objective of the study was to find differences and similarities in food retailers' buying behaviour across buyers, companies, and countries, by considering purchases of different food products. The study focused on differences and similarities in retail buyers' evaluations of product and supplier attributes. The first step was to review existing literature on retailer buying behaviour. The findings from this literature review (product and vendor attributes, background variables, and hypotheses) were applied to the European food retailers' context by incorporating information obtained from two meetings held with food retail buyers and food suppliers. Finally, a conjoint study was conducted among food retailers in 16 Western European countries, and theoretical and practical conclusions were drawn.

\section{Review and integration of research on retailers' buying behaviour}

To get an overview of existing research on retailer buying behaviour and to obtain a comprehensive platform for the present study, two literature studies, by Nilsson and Høst (1987) and Hansen and Skytte (1998), were reviewed. Nilsson and Høst (1987) made a very thorough review of studies on retailer merchandise requirements and identified no less than 394 criteria, reported in 34 studies. These criteria were analysed and the results showed that they could be grouped into ten main categories. Slight differences were found between the evaluation of manufacturer brands and retailer brands, but the main conclusion of the study was that, to the retailer, the manufacturer's price and marketing campaign were the most important criteria.
Hansen and Skytte (1998) examined a large number of international marketing journals and identified 71 references related to retailer buying behaviour. They concluded that most researchers had analysed the merchandise requirements, and some had also looked at required vendor attributes. Not many studies had connected the retailers' requirements to background variables. Only a few studies had been conducted on food retailers, and even fewer studies covered retailers in more than one country.

For the purposes of the present study, a number of papers were particularly thorough and informative. McGoldrick and Douglas (1983), who analysed the UK retail market for potato crisps, found that the retail buyers were highly interested in consumer demand for a particular brand, delivery reliability, general reliability of the supplier, and product quality. Pellegrini and Zanderighi (1991), who conducted a study among Italian retailers, stressed that retailers are interested in suppliers who are concerned about the retailers' handling costs and the space their products will occupy on the shelves. Ettenson and Wagner (1986)conducted a study among merchandise retail buyers, and discovered, among other things, that buyers with different retail buying experience use different judgement strategies when evaluating the saleability of merchandise. In one of the few studies conducted in more than one country (Sternquist, 1994), the focus was on the buyers' attitudes towards imported items. This study, which compared retail buyers in the apparel industry, showed that there were differences in buying behaviour between various countries. McLaughlin and Rao (1991) developed a model to determine the relative importance to retail buyers of various attributes of a new product. They tested their model on various grocery products (frozen foods, canned foods, dairy foods, beverages, snacks etc.) and, in general, they 
found that potential gross margin, vendor effort (test marketing, presentation, and promotion material), the presence of a bill-back provision, and expected category growth were the four most important buying criteria. But they also emphasised that 'different categories of products are evaluated by buyers differently' (McLaughlin and Rao, 1991, p. 155).

All of these studies provided inspiration for our own study by helping us to identify the most significant merchandise requirements, interesting background variables, expected relationships, and elements of an applicable methodology. .

\section{Choice of attributes for the study}

While conducting the literature review, we listed the attributes that the various researchers found to be most important.. This list encompassed 22 product and supplier attributes, which is far too many for a conjoint study (Green and Srinivasan, 1990). To reduce and refine the list, two meetings were held with food retail buyers and food suppliers. (Some of the retailers have stores in more than one European country and all the suppliers sell products to more than one country.) These food industry professionals were asked to indicate which attributes they considered to be most important and to add any important attributes that may be missing. One of the results of these discussions was that the attributes concerning physical distribution (e.g., lead-time, prompt delivery, and correct order procedures) were removed, as trade buyers took for granted that these attributes would be met.. However, the buyers considered itvery important that the food suppliers be able to supply sufficient quantities to meet the whole chain's demand for their products, as this was found to be a problem when working with small and medium-sized vendors. Another significant issue was whether the producer was national or foreign, because the buyers had found that consumers prefer national vendors for some products. If the producer was foreign, it was important to know whether the supplier had a sales office in the retailer's country - mainly for the purpose of intra-channel communication. These attributes were not considered in any of the former studies, but because the buyers and suppliers considered these attributes to be so important, they were added to our list. The discussions resulted in a list of 11 significant attributes, of which nine originatedfrom the literature review and two (sufficient quantity, national or international producer) were added by the discussion groups. The 11 attributes (variables) as applied to the cheese industry are shown in Table 1.

Table 1. Attributes for cheese (the attributes for fish are of course adjusted).

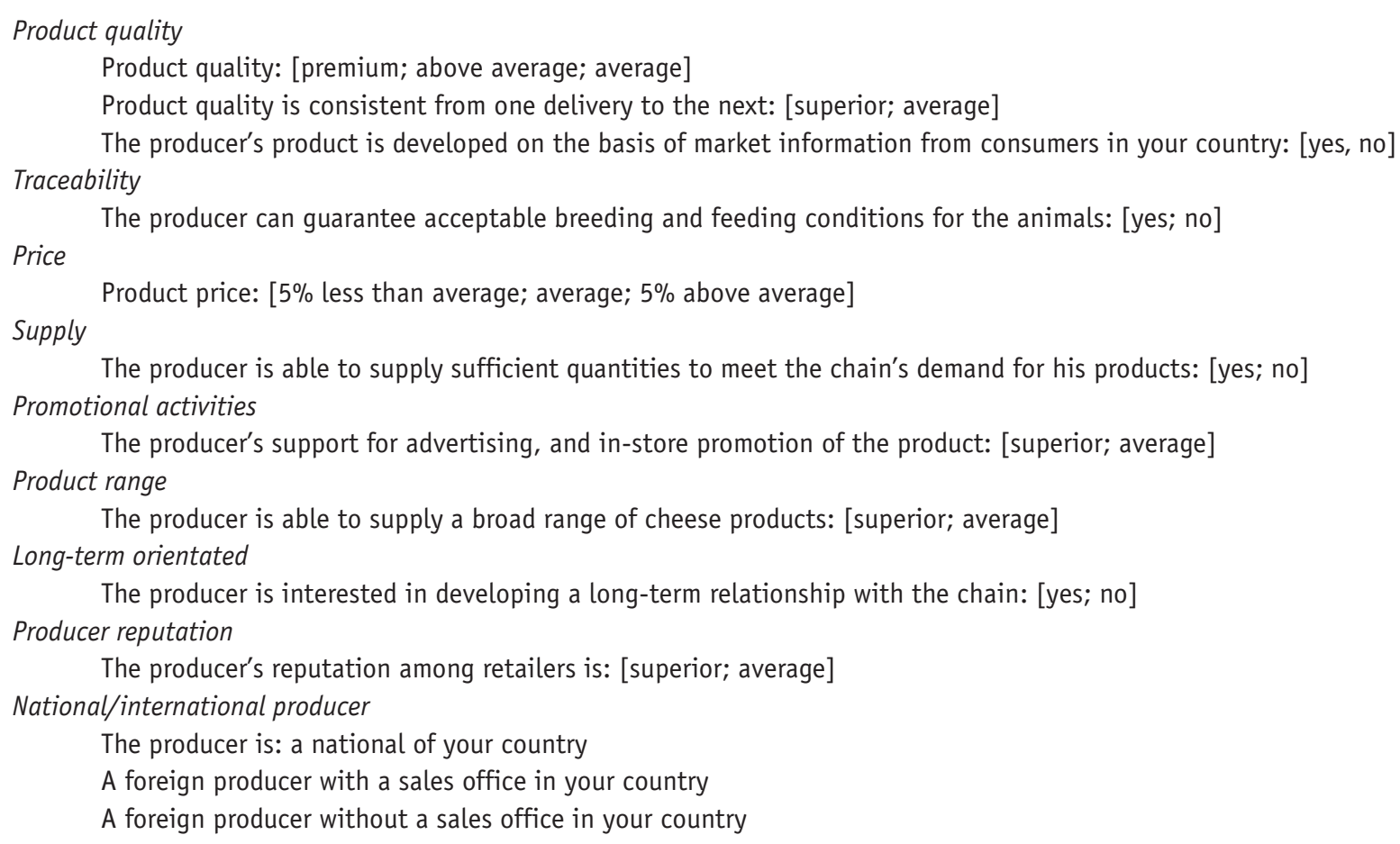


The 11 attributes do not all have the same structure. One is continuous (price), and the others are categorical in nature. Most of the attributes can, at the levels determined here, only be either present or absent (e.g., a foreign sales office), while some are present all the time at varying levels (e.g. product quality).

After the variable, the levels used on the various conjoint cards are indicated. These levels were taken from the literature review and refined during the meetings with the food sector discussion groups.

\section{Background variables}

The background variables, which were the most significant for this study, were the chain's home country (split into the 16 countries), the characteristics of the buying organisation, (channel formats, type of outlets, and number of outlets in the chain), the buying centre (number of members), the product (product positioning and category), current supplier (number of current suppliers and their country of origin) and the buyer (position, gender, qualifications and buying experience). These variables were found by choosing the background variables from papers in the literature review (Ettenson and Wagner, 1986; Hansen and Skytte (1998); McLaughlin and Rao, 1991; Sheth, 1981), followed by a refining process during the discussions with trade buyers and food producers. The background variables and the attributes are summarised in Table 2.

\section{Expected relationships}

The expected relationships between attributes and context (background) variables were developed based on the literature review and discussions with people from industry. As noted above, a few studies compared buyers from different countries and looked at the evaluation of imported products. Chang and Sternquist (1994) found significant differences in the buying behaviour of retailers in Taiwan and the United States due to differences in structure and other characteristics in the retail businesses in these countries. In another study on a major British grocery retailer's imports of packaged food, it was seen that retailers in general preferred products from their own country, but because of desired variety or a quality not otherwise available, they had to import (Shaw, Dawson and Blair, 1992). A four-country comparison study conducted among retail buyers in the apparel industry (in the United States, Japan, Hong Kong, and Taiwan) Sternquist (1994) found that the retail buyers' attitudes towards imported items differed, and there were differences in the buying process in the various countries.

Hirschman (1981) found that chain store buyers evaluated vendors differently than department stores buyers. She did not look at the same attributes as in our study (she analysed the apparel industry), but there may be a general difference in what different chain formats and types are looking for when evaluating vendors. According to Bhasin, Dickinson and Nandan (1995) retailers are generally more cost conscious when they buy products for their own labels than

Table 2. Background variables and product/vendor attributes affecting the buying decision.

\begin{tabular}{|c|c|c|}
\hline Background variables & Attributes & Dependent variable \\
\hline Buyer's nationality & Product quality & \\
\hline Characteristics of the buying organisation & Price & \\
\hline Characteristics of the buying centre & Consistency of product policy & \\
\hline Characteristics of the product & Market information & Product vendor evaluation: \\
\hline Characteristics of the current supplier & Traceability & $\begin{array}{l}\text { How likely is it that you will buy this product } \\
\text { from this supplier }\end{array}$ \\
\hline \multirow{6}{*}{ Characteristics of the buyer } & Sufficient quantities & [based on the above information] \\
\hline & Promotional activities & Not at all likely [0] to Very likely [10 \\
\hline & Product range & \\
\hline & Long-term oriented & \\
\hline & Supplier's reputation & \\
\hline & National/foreign supplier & \\
\hline
\end{tabular}


when they buy manufacturer brands. Shaw, Dawson and Blair (1992) also support this view in their study. This points to a difference in desired attributes when retailers buy products for different product positioning strategies. The Sheth model (1981) suggests that the supplier and product selection process may vary, among other things, by retailer size, retailer type, product type and product positioning.

The background information provided by these studies, combined with the results of our discussions with food industry professionals, allowed us to formulate expected relationships or hypotheses for this study (as listed in section 11).

\section{Choice of products for the study}

When choosing products to be included in the study, specific requirements had to be considered. The products had to be bought by all potential respondents in all 16 countries; they had to be important for the chains, i.e. the chains had to have a buying policy for each one; and ; the respondent chains had to have different buyers for the products. This would make it possible to compare the evaluation of the conjoint cards across the products, independent of the particular buyer. Theserequirements were met by choosing fish and cheese products for the study.

\section{Why conjoint analysis}

In studies of the impact of various factors on the listing of new products/suppliers by trade buyers, a broad spectrum of methods could be used. At one end is the realistic but time-consuming method of mapping all buying decisions made in a retail chain over a year (Mclaughlin and Rao, 1991). At the other end is the one-shot interview, in which the buyer is asked to weigh the decision criteria on a fiveor seven-point scale (Wall, Sommers and Wilcock, 1994). Unfortunately, this method is prone to generating 'subsequent rationalisation' and 'acceptable answers'.

Conjoint analysis is considered to be a sound compromise between these two extremes (Green, 1974; Green and Srinivasan, 1978, 1990; Wagner, Ettenson, and Parrish, 1989). It is much more realistic than the use of self-explicated weights and, at the same time, it opens up the possibility of using enough respondents to generalise the results. Moreover, by using an orthogonal experimental design, colinearity problems can be avoided. In a conjoint analysis, the respondent is given a set of cards, each describing a product in terms of the attributes of the product and/or the vendor, e.g. price, quality, and support for promotion. The attributes are varied over the card deck, and the respondent is asked to express his or her intention to buy the various products measured on a scale or by ranking of the cards. If the various product/vendor profiles are chosen in accordance with an adequate experimental plan, it is possible to map the utility function of the respondent using regression or (in the case of ranking) ordinal regression.

The aim of the conjoint analysis approach in this study was to analyse retailers' buying behaviour, i.e. to predict the buyers' preferences for multi-attribute options in a variety of vendor and product contexts. More precisely, the intention was to determine the relative importance of pre-selected product and vendor attributes.

\section{Potential respondents}

To analyse retail buyers' behaviour in the various countries, potential respondent companies had to be identified. To do this, a comprehensive set of secondary data from all 16 countries was collected and analysed. The references used to build a database of the retail enterprises included: Corporate Intelligence on Retailing (1995), European Retail Handbook (various editions), World Retail Directory and Sourcebook (various editions), a large number of retail handbooks from most of the countries in question, and a large number of annual reports from the retail enterprises in the various countries. A country-by-country list, comprising all food retailers with at least five shops was compiled, and a database of more than 900 European food retail chains was established. This database constituted the population for the study.

\section{Data collection}

It was presupposed that the buyers' evaluation of the product and supplier attributes depends on different background variables as discussed earlier. It was assumed that trade buyers express the retail chain's buying policy for a particular food product category when they evaluate the conjoint cards (Meyer and Rowan, 1977). At the same time, it was supposed that the intentions they express, when they mark how likely it is that they will buy the product from the vendor described on the cards, determine the chain's behaviour in connection with choice of product and supplier. That is to say, the behaviour is under volitional control and thus predictable from intentions. A basic view taken in the study was that trade buyers are expected to have strong beliefs about those aspects of their perceived environment that direct experience has demonstrated to be important for obtaining the consequences and goals they seek (Grønhaug and Venkatesh, 1991). It was also presupposed that this experience is encoded in their 
cognitive structures and the chain's buying policy. As a result, these routines and buying policies were expected to be a strong guide to their buying behaviour. Therefore, trade buyers were only interviewed about product types which they know well and usually buy. This ensured that only criteria from some pre-existing repertoire would be used, rather than responses created for the occasion (Neimeyer, 1985).

Many researchers (e.g. Ettenson and Wagner, 1986) stress the importance of placing the retail buyers in a familiar and meaningful environment when studying their judgements of conjoint cards. This study obtained a strong relationship between the judgement and the intention in two ways.Firstly, the literature review, followed refinement of the attributes based on discussions with food sector professionals, ensured that the attributes used in the conjoint study were very close to the real attributes used by the respondents. Secondly, the respondents were asked to evaluate the cards describing the type of products they buy 'most of'. Thus, the buyers were only asked to evaluate product types they were familiar and experienced with.

For each profile, the trade buyers were asked to indicate the likelihood that they would purchase the product from the vendor described. It is important to note that the evaluations took place in a comparison context. The trade buyers compared the product and supplier attributes described on the cards with 'the evoked set of choice options' (Sheth, 1981, p. 184), i.e. the set of products and suppliers used in comparing the options. But these evaluations also depend on the trade buyers' whole 'decision environment', i.e. the task environment interpreted by each trade buyer to be relevant in the choice situation at the time (Schommer, 1995).

As mentioned earlier, 11 criteria were selected for the study. But during the pre-test related to the development of the conjoint cards it became clear that 11 features on each card were too many to evaluate at one time.This would amount to an information overloadand would decrease the validity of the study. Therefore, a two-card design was developed that included seven features on one set of cards and six features on the other. Each card contained two overlapping bridging features, which were price and product quality. Two sets, each containing 17 cards, including holdout cards, were used. Each respondent had to evaluate all 34 profiles. The survey instrument was developed in English and then double-blind translated into 14 languages to achieve equivalence and to cover the 16 countries.

The literature review revealed that in some chains a buying committee evaluates supplier offerings, while in other chains one single buyer evaluates the offerings for each product category. However, asking only the person in charge of buying fish and cheese for an evaluation of the cards was not considered to be a problem, as the buying committee generally accepts about 90 per cent of the buyer's recommendations (McLaughlin and Rao, 1991).

\section{Conjoint analysis: mapping the utility functions of trade buyers}

The principle of bridging is to estimate (by regression through the origin) the factor by which to multiply the coefficients of the bridging factors in the second design in order to bring them in accordance with the corresponding coefficients in the first design. Then all the coefficients (including the constant) in the second design are multiplied by that factor - and the two estimated utility functions are then combined. The program used was Bretton-Clark's 'Bridger'.

The attributes quality and price had to be bridged, because if one of these attributes was missing in a conjoint analysis, the respondent would most certainly use the included attribute as an indicator of the other one. Generally it is expected that higher prices follow higher quality and vice versa. If both were missing the respondent would perhaps base his evaluations on assumptions about the levels of these two attributes, because the risk that people expect other attributes to 'follow' price or quality cannot be neglected.

However, it turned out that for several respondents these two attributes played so limited a role compared to some of the other attributes that the estimated utilities could be considered the result of a random process and, therefore, they did not correlate well between the two sets of cards. This problem deserves special mentioning, because one reason for conducting this study was that we believed that attributes other than the traditional four Ps were gaining in importance. It can be said that the failure of the two factors to bridge supported this hypothesis. However, from a technical point of view, the randomness connected with the evaluation of the bridging factors was a problem. This randomness emerged as very small differences in utility for the various levels of the attributes at the same time as high prices were preferred to low ones (for the same quality) and/or low quality to high quality (at the same price). To overcome this problem, the utility functions were reestimated using SYSTAT's (1999) non-linear least squares optimisation algorithm, placing order restrictions on the various coefficients. 
As seen in Table 1, the levels for most of the attributes are logically ordered, i.e., all other things being equal a respondent is expected to prefer lower prices to higher prices, higher quality to lower quality etc. Consequently, order restrictions were placed on all but the following: (1) support for promotion (as explained below), (2) willingness to engage in long-time relationships, and (3) national/foreign supplier.

As a respondent's breaking of a natural order generally was connected with low weight on the attribute in question and, therefore, could be assumed to include a large proportion of 'noise' - this procedure should most certainly increase the predictive validity of the study.

Only 11 of the 751 returned questionnaires were not bridged due to lack of variation in the utilities of the bridging factors. It was decided, however, to use only bridged questionnaires, in which (1) $R$ squared (between observed and predicted utility for a concept) was greater than the 0.30 for both sets of cards; (2) the correlation between the evaluations of the bridging attributes in both sets of cards was greater than 0.30; and (3) the average ratio between the utility for the same attribute levels for the bridging attributes was in the interval from 0.3 to 3.0 .

One could argue that these conditions are too restrictive, and in fact they reduced the number of 'successful' bridgings to 459 compared with the 751 returned questionnaires. It must, however, be emphasised that an analysis of the connection between the background variables and the evaluation of the crucial attributes does not necessitate a bridging, but can be performed on the separate card sets, as the only thing that matters in such an analysis is the variation in utilities for the attributes being analysed, and not their absolute value or their value relative to those of other attributes. Such an analysis can be based on about 740 questionnaires fulfilling the first restriction (a loss of less than 3 per cent). So the problem is not with the original conjoint jobs, but only with the bridging - and we will keep in mind that the relative failure of the bridging supports the point that quality and price are indeed losing relative importance as decision criteria.

The utility functions for fish and cheese in Table 3 look remarkably alike. The only differences is related to the tendency to prefer conducting business with suppliers in one's own country, which is more prominent among fish buyers than cheese buyers. Perhaps preferences for local cuisine weigh most heavily with regard to main course foods - such as fish - and have the least impact in buying delicacies such as cheese.Please note that while the crucial factor in the case of fish is whether the supplier is a national of the buyer's country, in the case of cheese it is whether the supplier is represented in the country.

Apart from these differences, there is great similarity between the two products: In general, the three factors of 'traceability', 'sufficient quantities', and 'long-term relationship' play a larger role than the traditional four Ps.

Among the four Ps, promotion can be considered negligible. In the interviews, many retailers said they prefer to run this activity with as little interference from the supplier as possible. As for price and quality, we found that the rather modest role these two traditional factors seem to play in the buyers' listing decisions is not a true picture of their influence. There are, however, certain minimum standards that the supplier should live up to in order to be taken into consideration standards which (as the interviews showed) are taken for granted by the buyer as well as the seller. It should be kept in mind that the relative influence of quality and price on the buying decision (provided they are up to the general standards) is even smaller than that reported in the table, because, as explained above, about one third of the conjoint jobs could not be satisfactorily bridged due to the small weight placed on these two attributes. Other more traditional factors such as consistency, market information, and product range also have very little influence.

We can conclude that the traditional product and supplier attributes have to be given less weight than other attributes, bit they cannot be neglected. A supplier has to live up to certain standards in order to be considered by the buyer, but he cannot use these attributes to differentiate himself from his competitors. As a means of differentiation and preference he has to use the three attributes mentioned above - and, possibly, establish a sales office in the buyer's country.

\section{The influence of (a few) background factors on the relative importance of decision criteria}

The next step once the average utility functions in Table 3 have been estimated is to try to establish connections between the background factors (mentioned in Table 2) and the relative importance of the various product/supplier attributes estimated in Table 3. A long list of hypotheses on these connections were developed based on the literature review and interviews with producers and trade buyers from the retail chains. As is obvious from Table 3, the most prominent attributes are 'traceability', 'sufficient quantities' and 'long-term relationship'. Within the limits of our study, it seemed most reasonable to concentrate on these few attributes and to limit ourselves to the small number of hypotheses mentioned below. The 'national/foreign' 
Table 3. Average utility functions for fish and cheese.

\begin{tabular}{|c|c|c|c|c|c|c|c|c|}
\hline \multirow[b]{2}{*}{ Quality of product } & \multicolumn{4}{|l|}{ FISH } & \multicolumn{4}{|l|}{ CHEESE } \\
\hline & $\mathrm{RI}=13$ & $\begin{array}{l}\text { average } \\
-0.84\end{array}$ & $\begin{array}{l}\text { above average } \\
0.15\end{array}$ & $\begin{array}{l}\text { premium } \\
0.69\end{array}$ & $\mathrm{RI}=12$ & $\begin{array}{l}\text { average } \\
-0.74\end{array}$ & $\begin{array}{l}\text { above average } \\
0.13\end{array}$ & $\begin{array}{l}\text { premium } \\
0.61\end{array}$ \\
\hline Product price & $\mathrm{RI}=8$ & -0.10 (vector) & & & $\mathrm{RI}=10$ & -0.11 (vector) & & \\
\hline Consistency & $\mathrm{RI}=6$ & $\begin{array}{l}\text { average } \\
-0.34\end{array}$ & $\begin{array}{l}\text { superior } \\
0.34\end{array}$ & & $R I=6$ & $\begin{array}{l}\text { average } \\
-0.34\end{array}$ & $\begin{array}{l}\text { superior } \\
0.34\end{array}$ & \\
\hline Market information & $\mathrm{RI}=6$ & $\begin{array}{l}\text { no } \\
-0.34\end{array}$ & $\begin{array}{l}\text { yes } \\
0.34\end{array}$ & & $\mathrm{RI}=6$ & $\begin{array}{l}\text { no } \\
-0.33\end{array}$ & $\begin{array}{l}\text { yes } \\
0.33\end{array}$ & \\
\hline Traceability & $\mathrm{RI}=11$ & $\begin{array}{l}\text { no } \\
-0.65\end{array}$ & $\begin{array}{l}\text { yes } \\
0.65\end{array}$ & & $\mathrm{RI}=12$ & $\begin{array}{l}\text { no } \\
-0.66\end{array}$ & $\begin{array}{l}\text { yes } \\
0.66\end{array}$ & \\
\hline Sufficient quantities & $\mathrm{RI}=16$ & $\begin{array}{l}\text { no } \\
-0.93\end{array}$ & $\begin{array}{l}\text { yes } \\
0.93\end{array}$ & & $\mathrm{RI}=17$ & $\begin{array}{l}\text { no } \\
-0.95\end{array}$ & $\begin{array}{l}\text { yes } \\
0.95\end{array}$ & \\
\hline Promotion & $\mathrm{RI}=2$ & $\begin{array}{l}\text { average } \\
-0.10\end{array}$ & $\begin{array}{l}\text { superior } \\
0.10\end{array}$ & & $\mathrm{RI}=3$ & $\begin{array}{l}\text { average } \\
-0.16\end{array}$ & $\begin{array}{l}\text { superior } \\
0.16\end{array}$ & \\
\hline Wide range & $\mathrm{RI}=5$ & $\begin{array}{l}\text { average } \\
-0.30\end{array}$ & $\begin{array}{l}\text { superior } \\
0.30\end{array}$ & & $\mathrm{RI}=5$ & $\begin{array}{l}\text { average } \\
-0.30\end{array}$ & $\begin{array}{l}\text { superior } \\
0.30\end{array}$ & \\
\hline Long-term relationship & $\mathrm{RI}=17$ & $\begin{array}{l}\text { no } \\
-1.02\end{array}$ & $\begin{array}{l}\text { yes } \\
1.02\end{array}$ & & $\mathrm{RI}=18$ & $\begin{array}{l}\text { no } \\
-1.02\end{array}$ & $\begin{array}{l}\text { yes } \\
1.02\end{array}$ & \\
\hline Reputation & $\mathrm{RI}=6$ & $\begin{array}{l}\text { average } \\
-0.37\end{array}$ & $\begin{array}{l}\text { superior } \\
0.37\end{array}$ & & $\mathrm{RI}=6$ & $\begin{array}{l}\text { average } \\
-0.35\end{array}$ & $\begin{array}{l}\text { superior } \\
0.35\end{array}$ & \\
\hline National/foreign & $\mathrm{RI}=10$ & $\begin{array}{l}\text { foreign without } \\
\text { sales office }\end{array}$ & $\begin{array}{l}\text { foreign with } \\
\text { sales office }\end{array}$ & National & $\mathrm{RI}=7$ & $\begin{array}{l}\text { foreign without } \\
\text { sales office }\end{array}$ & $\begin{array}{l}\text { foreign with } \\
\text { sales office }\end{array}$ & National \\
\hline & & -0.63 & -0.05 & 0.58 & & -0.44 & 0.09 & 0.35 \\
\hline
\end{tabular}

The 'part-worths' shows how much the utility for a product is changed measured on a 11-point scale as used in the questionnaire if the product has the attribute in question. For example, the utility of a fish product is increased by 0.30 if the vendor can offer a wide range of fish products. The 'part-worths' are normalised to add up to zero across values of the same factor.

$\mathrm{RI}$ is the relative importance of the attribute. They add up to $100(\%)$ across all attributes.

attribute was also included in our analysis, as this could be of great importance for business connections across borders.

The influence of the organisation of the chain on decision criteria: H1. Co-ops and chain retailers place more relative importance on 'traceability', 'sufficient quantities', and 'long-term relationship' than chains organised as wholesalersponsored and/or retailer-sponsored groups.

H2. Co-ops place more weight on the supplier being from their own country than do other channel formats.

The influence of outlet format on decision criteria:

H3. Chainswhich include department stores, hypermarkets, and/or supermarkets place higher weight on 'traceability' and 'long-term relationship' than do chains without these outlet forms; and the opposite is true for chainswhich include discounters and/or fishmongers/cheese shops.

H4. Chains which include supermarkets, hypermarkets, and/or discounters place higher weight on 'sufficient quantities' than do chains without these outlet forms; and the opposite is true for chains which include department stores, fishmongers/cheese shops, and/or delicatessen stores. H5. Chains which include fishmongers/cheese shops and/or delicatessen stores place higher weight on 'national/foreign' than do chains without these outlet forms; and the opposite is true for chains which include department stores, hypermarkets, supermarkets, and discounters.

The influence of chain size on decision criteria:

H6. The larger the chain, the more weight is placed on 'traceability', 'sufficient quantities', and 'long-term relationship', and the less weight on 'national/foreign'.

The influence of product positioning on decision criteria:

H7. When buying for one's own label (rather than buying a producer's brand) more weight is placed on 'traceability' and less weight on 'sufficient quantities' and 'long-term relationship'. 
Product and country differences:

H8. The four decision criteria play a larger role for fish buyers than for cheese buyers.

H9. Some country differences should be expected. For example, one may expect that 'traceability' plays a larger role in England, Germany and the Scandinavian countries than in the Mediterranean area, and perhaps that 'national/foreign' plays the largest role in France.

\section{Testing the hypotheses}

The normal procedure used to test hypotheses is statistical testing. However, this is meaningless in this situation because the data do not constitute a random sample from some universe. Rather they represent a census with some nonresponse. Therefore, larger chains were deliberately sampled and, consequently, the sample covers more than 60 per cent of the retail turnover for the two product classes. Statistical testing cannot meaningfully be applied in this study, because that would be tantamount to preferring a (small) sample for a census.

However, some statistical modelling (even if it is only used descriptively) is useful for the 'testing':

In the simple linear model

$y=\beta_{0}+\beta_{1} x+\varepsilon$

is supposed to represent the effect of all factors affecting $y$, but not explicitly included in the model - in the simplest case, all factors other than $x . \beta_{1}$ is the ceteris paribus effect of $x$ on $y$ if and only if

$\mathrm{E}(\varepsilon \mid \mathrm{x}) \mathrm{E}(\mathrm{x})$

That is, if and only if the expected value of excluded factors does not depend on $x$. In the analysis, $y$ plays the role of relative importance of some product/vendor attribute and $x$ is some background factor. Considering the background factors in the study, (2) would indeed be a very bold assumption. Therefore, it was decided to construct a set of linear models including all the background variables mentioned in section 4 in order to control for the most prominent ones. The result is shown in Table 4. As mentioned above, the $p$-values can only be considered to be descriptive, and considering that the data covers more than 60 per cent of the population measured in turnover, an attribute with a $p$-value smaller than 0.200 certainly deserves further investigation.

As mentioned in section 10, an analysis of the connection between the background variables and the weight placed on the various attributes does not necessitate a bridging but can be performed on the separate card sets. Therefore, this analysis is based on about 740 (a loss of less than 3 per cent, plus a small loss if some of the questions in the questionnaire are not answered). Consequently, the size of the relative importance in the following cannot be compared to those of Table 3. The relative importance sum to $100 \mathrm{per}$ cent irrespective of the number of attributes.

The great advantage of the linear model is that it allows one to estimate adjusted least square estimates of the mean values of the dependent variable for each value of a factor controlled for the influence of all other factors. This method allows us to examine the validity of our hypotheses. This, of course, is the same as taking the background factors out of $\varepsilon$ and, it therebyincreases the probability that assumption (2) holds. In Table 5 the factors which were 'significant' in Table 4 are shown in boldface.

The following results are revealed in Tables 4 and 5:

H1. This hypothesis is not supported by the data. On the contrary, retailer-sponsored groups place more weight on 'traceability' than do other chain organisations; and no differences exist related to 'sufficient quantities' and 'longterm relationships' .

H2. This hypothesis is not supported by the data.

H3. Part of this hypothesis is supported by the data: Chains which include discount stores and delicatessen stores place less weight on 'traceability' than chains which do not include these outlet forms. On the other hand, chains which include fishmongers/cheese shops seem to place more weight on 'long-time relationships' than do chains which do not include this outlet form.

H4. Part of this hypothesis is supported by the data: Chains which include discount stores place more weight on 'sufficient quantities' than chains which do not contain this outlet format. But contrary to the hypothesis, this is also the case for fishmongers/cheese shops.

H5. This hypothesis is partly supported by the data: Chains which include hypermarkets place less weight on 'national/foreign' than chains which do not include this outlet format (perhaps the same could be said about department stores).

H6. The influence of chain size appears to be too small to be of any use, even in the cases where it was declared 'significant' (i.e. 'sufficient quantities' and 'national/foreign'). However, it is important to remember that the model used for obtaining ceteris paribus conditions is linear, and the influence of chain size could be non-linear. In fact this seems to be the case: 'sufficient quantities' plays a significant role for all but the smallest chains; and even if the preference for suppliers who are willing to engage in long-time 
Table 4. 'Analysis of variance' of the hypotheses from section 11.

\begin{tabular}{|c|c|c|c|c|c|}
\hline Dep Var: RI_TRACE & N: 692 Multiple R: 0.518 & \multicolumn{2}{|c|}{ Squared multiple R: 0.269} & \multirow[b]{2}{*}{ F-ratio } & \multirow[b]{2}{*}{$\mathrm{P}$} \\
\hline Source & Sum-of-Squares & $d f$ & Mean-Square & & \\
\hline COUNTRY\$ & 51162.795 & 16 & 3197.675 & 12.809 & $0.000 *$ \\
\hline CHANNEL & 2076.554 & 5 & 415.311 & 1.664 & $0.141^{*}$ \\
\hline DEPARTM & 7.278 & 1 & 7.278 & 0.029 & 0.864 \\
\hline HYPERM & 317.629 & 1 & 317.629 & 1.272 & 0.260 \\
\hline SUPERM & 272.856 & 1 & 272.856 & 1.093 & 0.296 \\
\hline DISCOUNT & 942.135 & 1 & 942.135 & 3.774 & $0.052^{*}$ \\
\hline SPECIAL & 117.002 & 1 & 117.002 & 0.469 & 0.494 \\
\hline DELICAT & 916.157 & 1 & 916.157 & 3.670 & $0.056^{*}$ \\
\hline OTHER & 29.845 & 1 & 29.845 & 0.120 & 0.730 \\
\hline OUTLETNO & 82.719 & 1 & 82.719 & 0.331 & 0.565 \\
\hline POSIMOST & 297.968 & 2 & 148.984 & 0.597 & 0.551 \\
\hline PRODUCT\$ & 744.354 & 1 & 744.354 & 2.982 & $0.085^{*}$ \\
\hline Error & 164518.444 & 659 & 249.649 & & \\
\hline Dep Var: RI_SUFF & N: 692 & \multicolumn{2}{|c|}{ Multiple R: 0.308} & \multicolumn{2}{|c|}{ Squared multiple R: 0.095} \\
\hline Source & Sum-of-Squares & $d f$ & Mean-Square & F-ratio & $P$ \\
\hline COUNTRY\$ & 12624.056 & 16 & 789.003 & 2.954 & $0.000^{*}$ \\
\hline CHANNEL & 822.216 & 5 & 164.443 & 0.616 & 0.688 \\
\hline DEPARTM & 39.111 & 1 & 39.111 & 0.146 & 0.702 \\
\hline HYPERM & 8.164 & 1 & 8.164 & 0.031 & 0.861 \\
\hline SUPERM & 77.664 & 1 & 77.664 & 0.291 & 0.590 \\
\hline DISCOUNT & 651.712 & 1 & 651.712 & 2.440 & $0.119 *$ \\
\hline SPECIAL & 1177.627 & 1 & 1177.627 & 4.410 & $0.036^{*}$ \\
\hline DELICAT & 5.752 & 1 & 5.752 & 0.022 & 0.883 \\
\hline OTHER & 316.677 & 1 & 316.677 & 1.186 & 0.277 \\
\hline OUTLETNO & 779.762 & 1 & 779.762 & 2.920 & $0.088^{*}$ \\
\hline POSIMOST & 450.960 & 2 & 225.480 & 0.844 & 0.430 \\
\hline PRODUCT\$ & 7.632 & 1 & 7.632 & 0.029 & 0.866 \\
\hline Error & 175990.772 & 659 & 267.057 & & \\
\hline Dep Var: RI_LONG & N: 701 & \multicolumn{2}{|c|}{ Multiple R: 0.360} & \multicolumn{2}{|c|}{ Squared multiple R: 0.130} \\
\hline Source & Sum-of-Squares & $d f$ & Mean-Square & F-ratio & $P$ \\
\hline COUNTRY\$ & 22889.319 & 16 & 1430.582 & 4.859 & 0.000 * \\
\hline CHANNEL & 1749.899 & 5 & 349.980 & 1.189 & 0.313 \\
\hline DEPARTM & 2018.087 & 1 & 2018.087 & 6.855 & 0.009 * \\
\hline HYPERM & 44.461 & 1 & 44.461 & 0.151 & 0.698 \\
\hline SUPERM & 289.571 & 1 & 289.571 & 0.984 & 0.322 \\
\hline DISCOUNT & 553.576 & 1 & 553.576 & 1.880 & $0.171^{*}$ \\
\hline SPECIAL & 764.097 & 1 & 764.097 & 2.595 & $0.108^{*}$ \\
\hline DELICAT & 681.153 & 1 & 681.153 & 2.314 & 0.129 * \\
\hline OTHER & 17.421 & 1 & 17.421 & 0.059 & 0.808 \\
\hline OUTLETNO & 0.288 & 1 & 0.288 & 0.001 & 0.975 \\
\hline POSIMOST & 234.022 & 2 & 117.011 & 0.397 & 0.672 \\
\hline PRODUCT\$ & 1313.785 & 1 & 1313.785 & 4.462 & $0.035^{*}$ \\
\hline Error & 196668.200 & 668 & 294.413 & & \\
\hline
\end{tabular}


Table 4. Continued.

\begin{tabular}{|c|c|c|c|c|c|}
\hline Dep Var: RI_NATIONAL & N: 701 & \multicolumn{2}{|c|}{ Multiple R: 0.375} & \multicolumn{2}{|c|}{ Squared multiple R: 0.141} \\
\hline Source & Sum-of-Squares & $d f$ & Mean-Square & F-ratio & $\mathrm{P}$ \\
\hline COUNTRY\$ & 12308.342 & 16 & 769.271 & 4.288 & $0.000 *$ \\
\hline CHANNEL & 534.704 & 5 & 106.941 & 0.596 & 0.703 \\
\hline DEPARTM & 262.112 & 1 & 262.112 & 1.461 & 0.227 \\
\hline HYPERM & 870.578 & 1 & 870.578 & 4.852 & $0.028 *$ \\
\hline SUPERM & 128.275 & 1 & 128.275 & 0.715 & 0.398 \\
\hline DISCOUNT & 0.049 & 1 & 0.049 & 0.000 & 0.987 \\
\hline SPECIAL & 18.168 & 1 & 18.168 & 0.101 & 0.750 \\
\hline DELICAT & 26.579 & 1 & 26.579 & 0.148 & 0.700 \\
\hline OTHER & 19.394 & 1 & 19.394 & 0.108 & 0.742 \\
\hline OUTLETNO & 464.253 & 1 & 464.253 & 2.588 & $0.108 *$ \\
\hline POSIMOST & 184.785 & 2 & 92.393 & 0.515 & 0.598 \\
\hline PRODUCT\$ & 1321.732 & 1 & 1321.732 & 7.367 & $0.007^{*}$ \\
\hline Error & 119846.094 & 668 & 179.410 & & \\
\hline RI_TRACE & \multicolumn{5}{|c|}{$=$ relative importance of 'traceability' } \\
\hline RI_SUFF & \multicolumn{5}{|c|}{$=$ relative importance of 'sufficient quantities' } \\
\hline RI_LONG & \multicolumn{5}{|c|}{$=$ relative importance of 'long-time relationship' } \\
\hline RI_NAT & \multicolumn{5}{|c|}{$=$ relative importance of 'national/foreign' } \\
\hline COUNTRY\$ & \multicolumn{5}{|c|}{$=$ country of the retail chain } \\
\hline CHANNEL & \multicolumn{5}{|c|}{$=$ the organisation of the chain: co-op., chain retailer, wholesaler-sponsored etc. } \\
\hline DEPARTM & \multicolumn{5}{|c|}{$=$ whether the chain includes department stores (coded 0.1 ) } \\
\hline HYPERM & \multicolumn{5}{|c|}{$=$ whether the chain includes hypermarkets (coded 0.1 ) } \\
\hline SUPERM & \multicolumn{5}{|c|}{$=$ whether the chain includes supermarkets (coded 0.1 ) } \\
\hline DISCOUNT & \multicolumn{5}{|c|}{$=$ whether the chain includes discount stores (coded 0.1 ) } \\
\hline SPECIAL & \multicolumn{5}{|c|}{$=$ whether the chain includes speciality stores (fishmongers/cheese??) (coded 0.1) } \\
\hline DELICAT & \multicolumn{5}{|c|}{$=$ whether the chain includes delicatessen shops (coded 0.1 ) } \\
\hline OTHER & \multicolumn{5}{|c|}{$=$ whether the chain includes other forms of shops (coded 0.1 ) } \\
\hline OUTLETNO & \multicolumn{5}{|c|}{$=$ number of outlets of the chain } \\
\hline POSIMOST & \multicolumn{5}{|c|}{$=$ whether the goods are bought as producer's brand, retail brand or have no name } \\
\hline PRODUCT\$ & \multicolumn{5}{|l|}{$=$ fish or cheese } \\
\hline
\end{tabular}

relationships is relatively independent of chain size, a further study of the relationship shows a tendency for this factor to play a larger role for very small and very large chains. So, while the preference for suppliers who are willing to engage in long-time relationships is relatively independent of chain size, the motives could be different: larger chains want cooperation on product development, etc., and smaller chains (with few resources) could find it desirable to have a fixed supplier, to minimise the costs involved in establishing new supplier relationships.

H7. This hypothesis is not supported by the data.

H8. The data show some mixed results: 'traceability' and 'long-time relationship' seem to be more important for cheese buyers than for fish buyers and 'national/foreign' plays the largest role for fish buyers. No difference was found in relation to 'sufficient quantities'. However, all the differences are too small to have practical implications.
H9. Chains in Sweden, Switzerland and, above all, in Germany place a lot of weight on 'traceability', while the opposite is true for chains in Austria, Belgium, Finland and the UK. 'Significant quantities' plays an important role in most of the countries, but it is most pronounced in Denmark. Chains in Sweden (followed by those in Germany and Denmark) place the most weight on 'long-time relationships', and at the other extreme we find the Mediterranean countries of Greece, Spain and France. Switzerland and Portugal clearly emerge as the countries where 'national/foreign' has the smallest impact on buying decisions. The variance among the other countries is not very large although Mediterranean countries are among the countries where this attribute has the smallest effect. 
Table 5. Adjusted least-square estimates of relative importance based on the linear model.

\begin{tabular}{|c|c|c|c|c|c|}
\hline \multirow[t]{2}{*}{ Background variable } & \multirow[t]{2}{*}{ Value of background variable } & TRACE & SUFF & LONG & NAT \\
\hline & & \multicolumn{2}{|c|}{$\begin{array}{l}\text { Based on } \\
1 \text { card deck }\end{array}$} & \multicolumn{2}{|c|}{$\begin{array}{l}\text { Based on } \\
2 \text { card deck }\end{array}$} \\
\hline \multirow[t]{16}{*}{ Country } & A & 3 & 29 & 31 & 15 \\
\hline & B & 6 & 31 & 30 & 14 \\
\hline & $\mathrm{CH}$ & 19 & 30 & 23 & 8 \\
\hline & $\mathrm{D}$ & 28 & 31 & 36 & 13 \\
\hline & DK & 12 & 42 & 33 & 19 \\
\hline & $\mathrm{E}$ & 8 & 29 & 20 & 23 \\
\hline & $\mathrm{F}$ & 12 & 24 & 24 & 19 \\
\hline & GR & 2 & 20 & 14 & 21 \\
\hline & $\mathrm{I}$ & 12 & 34 & 31 & 21 \\
\hline & IRL & 14 & 16 & 27 & 14 \\
\hline & $\mathrm{N}$ & 9 & 26 & 31 & 14 \\
\hline & $\mathrm{NL}$ & 7 & 34 & 27 & 21 \\
\hline & $P$ & 15 & 27 & 29 & 9 \\
\hline & $\mathrm{S}$ & 19 & 29 & 40 & 13 \\
\hline & SF & 8 & 36 & 29 & 16 \\
\hline & UK & 9 & 36 & 28 & 17 \\
\hline \multirow[t]{6}{*}{ Channel organisation } & chain retailer & 13 & 28 & 31 & 19 \\
\hline & co-ops & 9 & 27 & 26 & 19 \\
\hline & wholesaler-sponsored voluntary group & 10 & 28 & 28 & 19 \\
\hline & retailer sponsored voluntary group & 16 & 27 & 27 & 16 \\
\hline & franchise system & 12 & 35 & 28 & 21 \\
\hline & other kinds of channel & 11 & 30 & 32 & 17 \\
\hline \multirow[t]{14}{*}{ Outlet format } & chain includes department stores & 12 & 30 & 32 & 17 \\
\hline & chain does not include department stores & 12 & 29 & 25 & 20 \\
\hline & chain includes hypermarkets & 13 & 29 & 28 & 17 \\
\hline & chain does not include hypermarkets & 11 & 29 & 29 & 20 \\
\hline & chain includes supermarkets & 13 & 30 & 30 & 19 \\
\hline & chain does not include supermarkets & 11 & 29 & 28 & 18 \\
\hline & chain includes discount stores & 10 & 31 & 27 & 19 \\
\hline & chain does not include discount stores & 14 & 28 & 30 & 19 \\
\hline & chain includes fishmongers/cheese shops & 11 & 33 & 32 & 18 \\
\hline & chain does not include fishmongers/cheese shops & 13 & 26 & 26 & 19 \\
\hline & chain includes delicatessen stores & 9 & 29 & 26 & 18 \\
\hline & chain does not include delicatessen stores & 15 & 29 & 31 & 19 \\
\hline & chain includes other type of outlet & 12 & 30 & 30 & 18 \\
\hline & chain does not include other type of outlet & 12 & 28 & 29 & 19 \\
\hline \multirow[t]{2}{*}{ Number of outlets } & This is coded as a vector variable. & 0 & 0 & -0 & 0 \\
\hline & The regressions coefficient is 0 to the first three $d$ & al places & & & \\
\hline \multirow[t]{3}{*}{ Position strategy } & Retailer brand & 11 & 30 & 28 & 18 \\
\hline & Manufacturer's brand & 11 & 30 & 29 & 19 \\
\hline & No-name product & 13 & 28 & 30 & 18 \\
\hline \multirow[t]{2}{*}{ Product } & Fish & 11 & 29 & 27 & 20 \\
\hline & Cheese & 13 & 29 & 30 & 17 \\
\hline
\end{tabular}

For 'country' a few of the smallest and largest values are shown in boldface, and for the other attributes 'significant' values are in boldface 


\section{Theoretical contributions}

This study showed that food retail buyers no longer focus on the four Ps (as these are taken for granted). They are now looking for new attributes, namely, traceability, sufficient quantities, long-term relationships and depending on product type - national producer or at least a producer who has a sales office in the retail chain's home country. The study also showed that the background variables used (variables connected to the chains structure and to characteristics of the buyers) are not good indicators of what attributes the retail chains are looking for. Furthermore, the retailers in the 16 countries included in the study are, to a large extent, looking for the same attributes. Further research will seek to examine why this is the case, but one possible explanation could be that retailers all over Western Europe (because of their relatively close contact and a high level of international public communication) develop internationally shared beliefs, which guide their choices of attributes and their buying behaviour.

\section{A new agenda for food producers}

These results support the introduction of a new agenda for food producers. The demand for traceability means that the producer must have information on a wide range of issues that goes all the way back to the primary producer. When sufficient quantity for the whole chain (often several hundred shops) is a requirement, horizontal co-operation among suppliers or the use of sub-suppliers can be necessary. For some food producers, the demand for long-term relationships with the retail chains requires a change in attitude about how to do business. Other producers only have to develop more competencies to handle the vertical co-operation with the retailers. The most positive finding of this study (for the food producers) may be that almost all retailers in Western Europe demand the same attributes. This means that it may become easier for producers to export their goods to other Western European countries.

\section{Further research}

As mentioned above, the results presented in this article focus only on a very small number of the hypotheses developed for this study. The next step is to include all the context variables in the analysis. As some data (the various conjoint evaluations) vary with the respondent, while others are measured at organisation level, the analysis should be based on a multi-level model. In such a model, the parameters at the lowest level (the utilities) are dependent upon variables at the higher level.

\section{References}

Bhasin, A., R. Dickinson, and S. Nandan, 1995. Retailer Brands: A Channel Perspective: The United States. Journal of Marketing Channels 4, 4, 17-36.

Chang, L. and B. Sternquist, 1994. Product Procurement: Comparision of Taiwanese and US Retail Companies. International Review of Retail, Distribution and Consumer Research 4, 1, 61-82.

Ettenson, R. and J. Wagner, 1986. Retail buyers' saleability judgements: A comparison of information use across three levels of experience. Journal of Retailing 62, 1, 41-63.

Green, P.E, 1974. On the design choice experiments involving multi-factor alternatives. Journal of Consumer Research 1, September, 61-68.

Green, P.E. and V. Srinivasan, 1978. Conjoint analysis in consumer research: Issues and outlook. Journal of Consumer Research 5, September, 103-123.

Green, P.E. and V. Srinivasan, 1990. Conjoint analysis in marketing: New developments with implications for research and marketing. Journal of Marketing, 54, 3-19.

Grønhaug, K. and A. Venkatesh, 1991. Needs and Need Recognition in Organisational Buying. European Journal of Marketing 25, 2, 17-32.

Hansen, T.H. and H. Skytte, 1998, Retailers' choice of suppliers and products. The International Review of Retail, Distribution and Consumer Research, 8, 3, 277-301.

Hirschman, E.C., 1981. Retailing and the Production of Popular Culture. Theory in Retailing: Traditional and Nontraditional Sources. R. W. Stampfl and E. C. Hirschman (Editors) Chicago, American Marketing Association, 71-83.

McGoldrick, P.J. and R.A. Douglas, 1983. Factors Influencing the Choice of a Supplier by Grocery Distributors. European Journal of Marketing 17, 5, 13-27.

McLaughlin, E.W. and V.R. Rao, 1991. Decision criteria for new product acceptance and success. New York: Quorum Books.

Meyer, J.W. and B. Rowan, 1977. Institutionalized Organizations: Formal Structure as Myth and Ceremony. American Journal of Sociology 83, 2, 340-363.

Neimeyer, R.A., 1985. Problems and prospects in personal construct theory, in Issues and Approaches in Personal Construct Theory. London: Academic Press, , 143-171.

Nilsson, J. and V. Høst, 1987. Reseller Assortment Decision Criteria. Aarhus: Aarhus University Press.

Pellegrini, L. and L. Zanderighi, 1991. New Products: manufacturers' versus retailers' decision criteria. International Journal of Retail, Distribution \& Consumer Research 1, 2, 149-174.

Rao, V.R. and E.W. McLaughlin, 1989. Modelling the decision to add new products by channel intermediaries. Journal of Marketing 53, January, 80-88 
Schommer, J.C., 1995. Definition and measurement of environmental uncertainty in channels of distribution research: A Proposal and Pilot Test. Journal of Marketing Channels 4, 3 , 53-73.

Shaw, S.A., J.A. Dawson, and L.M.A. Blair, 1992. Imported foods in a British supermarket chain: buyer decisions in Safeway. International Review of Retail, Distribution and Consumer Research 2, 1, 35-57.

Sheth, J.N., 1981. A theory of merchandise buying behavior, In: Theory in retailing. R. W. Stampfl and E. C. Hirschman (Editors). American Marketing Association, 180-189.

Sternquist, B., 1994. Gatekeepers of consumer choice: a four-country comparison of retail buyers. International Review of Retail, Distribution and Consumer Research 4, 2, 159-176.

Wagner, J., R. Ettenson and J. Parrish, 1989. Vendor selection among retail buyers: An analysis by merchandise division. Journal of Retailing 65, 1, 58 - 79.

Wall, M., M. Sommers and A. Wilcock, 1994. The retail buying of fashion goods: underlying themes of the sourcing process. International Review of Retail Distribution and Consumer Research 4, 2, 177-193.

\section{Anonymous}

Bretton-Clark (publ.) 1988, Bridger.

Corporate Intelligence on Retailing, 1995

European Retail Handbook (various editions)

SPSS Science (publ.) 1999, SYSTAT 9. Chicago.

World Retail Directory and Sourcebook (Various editions) 